Progress reports

\title{
Sea Levels: Science and Society
}

\section{Robin Edwards}

School of Natural Sciences, Museum Building, Trinity College Dublin, Dublin 2, Ireland.

\section{Introduction}

"Earth Science for Society" is the tagline for the International Year of Planet Earth (IYPE). This joint initiative by the United Nations Educational, Scientific and Cultural Organisation (UNESCO) and the International Union of Geological Sciences, aims to promote the activities of Earth scientists and encourage effective use of their knowledge by society. The fourth assessment report (AR4) of the Intergovernmental Panel on Climate Change (IPCC) Working Group II, which considers impacts, adaptation and vulnerability, is an example of work that places current scientific understanding in a policy-relevant context (Parry et al., 2007). The AR4 highlights that coasts are already experiencing adverse change linked to climate and sea level. Risks such as those associated with coastal erosion will increase over the coming decades and increased human pressures on the coastal zone will exacerbate their impacts, which will be particularly challenging for developing countries (Nicholls et al., 2007).

This review focuses on sea level change over timescales of direct relevance to human societies. It begins with an update on recent patterns and rates of sea level rise before describing some improvements in our understanding of ocean volume change with particular reference to the role of ice sheet dynamics. It also examines the coastal impacts of abrupt events such as storms, hurricanes and tsunamis, before concluding with a brief comment on the relationship between sea level, coastal change and society.

\section{Recent Rates of Sea Level Change}

Rising sea levels increase the risk of adverse coastal impacts, such as flooding and erosion, whilst accelerations in the rate of rise may initiate profound morphological changes, especially in sediment limited contexts (Nicholls et al., 2007). Studies of 
instrumental data indicate that sea level rise during the 1990s was anomalously fast when compared to the $20^{\text {th }}$ century as a whole (Holgate and Woodworth, 2004; Bindoff et al., 2007; Church et al., 2008). However, rates of rise exhibit substantial natural variability at a range of timescales and so interpreting the significance of such changes is a non-trivial task (Church et al., 2005; White et al., 2005; Church \& White, 2006). Various filtering and spectral analysis techniques can be employed to identify and remove annual to decadal fluctuations and distil longer-term non-linear trends (e.g. Jevrejeva et al., 2005; 2006). A broadly consistent pattern emerges across studies using different data compilations and methods, although Woodworth (2006) cautions that ultimately, these studies are not truly independent, since they are based on the same global dataset of tide gauge stations with inherent limitations relating to distribution and record length.

Prior to the 1930s, the rate of sea level rise was around $1 \mathrm{~mm} / \mathrm{yr}$, but this more than doubled during the interval between the late 1930 s and late 1950 s, peaking at 2.5 $\mathrm{mm} / \mathrm{yr}$, before falling to less than $2 \mathrm{~mm} / \mathrm{yr}$ from the late 1950s to the 1980s (Church et al., 2008). Whilst Church et al. (2008) infer that the most rapid rates of sea level rise took place during the 1990s, Jevrejeva et al. (2008) suggest that when decadal variability is accounted for, the rapid rise of $2.5 \mathrm{~mm} / \mathrm{yr}$ between $1920-1950$ is the fastest rate recorded during the last 300 years. Using the long tide gauge records of Amsterdam, Liverpool and Stockholm, Jevrejeva et al. (2008) go on to suggest that a significant change in the rate of sea level rise is evident after the $1780 \mathrm{~s}$, equating to an acceleration of $0.01 \mathrm{~mm} / \mathrm{yr}^{2}$.

Woodworth et al. (in press) agree that the strongest patterns of change to emerge from tide gauge records are the acceleration during the 1920s and 1930s, and the deceleration that took place after 1960, both of which have been commented upon in the literature for some time (e.g. Gutenberg, 1941; Barnett, 1984; Woodworth 1987, 1990; Tsimplis and Baker, 2000; Tsimplis \& Josey, 2001, Tsimplis et al., 2005). However, their analysis shows that the precise timing and magnitude of rate changes varies between ocean basins, and whilst the globally averaged reconstructions of Church and White (2006) and Jevrejeva et al. (2006) exhibit similar patterns of acceleration and deceleration, these are strongly influenced by the tide gauge records from Europe and N. America. In contrast, some regions outside of these areas exhibit changes that diverge from this 'global' pattern, and both inflexions are not always apparent in the same record. Woodworth et al. (in press) conclude that divergences from these general patterns are most likely caused by the influence of factors associated with atmospheric and ocean circulation change. 
Jevrejeva et al. (2008) note the existence of a 60-70 year periodicity in the rate of sea level rise that extends back into the pre-industrial period. A similar pattern of variability has been noted previously in records of sea surface temperature, sea level pressure and European air temperature and may be indicative of an underlying Atlantic driving mechanism. One possible driver is variation in the strength of the meridional overturning circulation (Delworth \& Mann, 2000), perhaps through the advection of density anomalies (Dijkstra \& Ghil, 2005), although observational data are at present insufficient to determine this, whilst model simulations do not reproduce strong patterns on these timescales (Knight et al., 2005).

Over shorter timescales of years to a decade or so, other processes become significant. For example, the reduction in the rate of sea level rise that occurred during the 1960s coincides with a series of explosive volcanic eruptions that are inferred to have produced cooling and contraction of the upper ocean (Church et al., 2005; Gleckler et al., 2006a,b; Jevrejeva et al., 2006), although Woodworth et al. (in press) note that larger contributions are required to explain the post-1960 flattening observed in many individual records. Circulation changes associated with large-scale atmospheric modes, such as the North Atlantic Oscillation (NAO) and the El Nino Southern Oscillation (ENSO), are significant since they can result in the redistribution of water masses within an ocean basin (Trenberth et al., 2002; Jevrejeva et al., 2006; Baines \& Folland, 2007). Miller \& Douglas (2007) suggest that gyre-scale wind forcing may potentially cause gyres to spin up or down causing water to migrate into or out from their centres. Consequently, average basin wide trends may be hard to measure from coastal tide gauges, and variability between basins further complicates the application of approaches that rely on recent spatial patterns inferred from satellite data (e.g. Church and White, 2006).

Improvements in our understanding of these kinds of change will rely on the development of new records covering the last century or more. Tide gauge "archaeology" may provide one means of improving instrumental data coverage (Church et al., 2008; Woodworth et al., in press), but high precision geologically based reconstructions also have an important role to play. In low latitudes, microatolls can provide decimetre and multi-decadal to century scale relative sea-level (RSL) reconstructions which, given favourable conditions of growth and preservation, may record subtle variability associated with ENSO-related changes in sea surface temperature and wind stress (e.g. Goodwin \& Harvey, 2008). In higher latitudes, microfossil-based investigations of saltmarsh sediments, such as those reviewed in the previous Progress Report, can produce records of similar resolution (Edwards, 
2007). In a recent example of this approach, Gehrels et al. (2008) produce a 500 year RSL record from south-eastern New Zealand, generated from foraminiferabased sea level index points and a composite chronology established from AMS radiocarbon dating, lead concentrations, stable lead isotopes, pollen markers, charcoal concentrations and caesium- 137 .

The production of a robust chronology is a critical element in developing this type of high-resolution reconstruction. Traditional sea level investigations have relied on the use of radiocarbon dating, but this has reduced effectiveness in the last few hundred years. Shorter-lived radionuclides, (e.g. $\mathrm{Pb}^{210}$ and $\mathrm{Cs}^{137}$ ) can assist in developing chronologies covering the last 100 years, but are associated with limitations such as the post-depositional migration of caesium under certain conditions (e.g. Smith, 2001; Harvey et al., 2007). An alternative potential approach for dealing with radiocarbon-based chronologies spanning the last century is "bomb-spike" calibration (Turetsky et al., 2004). This approach is based upon the fact that there is a rapid increase or spike in atmospheric radiocarbon after $1950 \mathrm{AD}$ as a consequence of nuclear weapons testing, and this has been used to constrain the age of organic-rich sediments (Goodsite et al., 2001; McGee et al., 2004). Marshall et al. (2007) have successfully applied this approach to saltmarsh sediments and show how the careful combination of multiple lines of dating evidence can result in an improved, more secure accumulation history. Their analysis, which includes the use of high precision (extended counting) radiocarbon dates to reduce age uncertainties, also indicates that concerns surrounding the use of $\mathrm{Pb}^{210}$ for dating saltmarsh sediments are well founded.

\section{Ocean Volume Change}

The pronounced variability of sea level over a range of timescales complicates reliable determination of changes that are driven by rising temperatures alone. The recent debate surrounding attempts to infer future sea level rise from global temperature also illustrates that conclusions are sensitive to the choice of data manipulation and statistical techniques used (e.g. Rahmstorf, 2007a; Holgate et al., 2007; Schmith et al., 2007; Rahmstorf, 2007b). Thermal expansion and melting landbased ice appear to be the main factors contributing to both the sea level rise observed during the $20^{\text {th }}$ century, and the rise predicted for the $21^{\text {st }}$ century (Bindoff et al., 2007; Meehl et al., 2007; Church et al., 2008). Improvements in the estimates of both terms are necessary if the sea level budget is to be closed satisfactorily and projections of future sea level rise are to be better constrained (see Edwards, 2007). 
In some cases, improvements can come from better observational data and alternative methods of analysis. For example, the recent identification of a systematic warm bias in eXpendable Bathymetric Thermograph (XBT) data (Gouretski \& Koltermann, 2007; Wijffels et al., 2008) means that earlier estimates of ocean thermal expansion require revision. Domingues et al. (2008) correct for this bias in their revised estimate of upper ocean thermal expansion, resulting in a $40 \%$ reduction for the period 1993-2003. They also use an alternative statistical approach to deal with the sparse nature of the observational database, and conclude that for the period 1960-2003, previous estimates of thermal expansion for the upper $700 \mathrm{~m}$ were underestimated by around $50 \%$. The authors note that their new globally averaged estimates are almost identical to the rates presented by Jevrejeva et al. (2006), although they diverge from satellite altimeter observations after 1999 for reasons that are not yet understood.

In other cases, some fundamental advances in the current state of knowledge are required before processes are sufficiently well quantified that they can be reliably modelled. Perhaps the best example of this is the uncertainty surrounding the dynamic nature of ice sheet response to climate change (Meehl et al., 2007). One of the potential mechanisms that may bring about rapid ice sheet change is the introduction of meltwater to the base of an ice sheet, lubricating it and resulting in an acceleration and increased discharge (Joughin et al., 2004; Rignot \& Kanagaratnam, 2006). Recent studies suggest that it is not simply the amount of meltwater reaching the base that is important, but rather how this water supply varies through time and its relationship to the capacity of the subglacial hydraulic system. Bartholomaus et al. (2008) show that glacier velocity increases when englacial and subglacial storage is increasing, but that sustained high rates of supply do not produce continued rapid motion. They suggest this is because subglacial hydraulic systems adjust to accommodate increased water inputs. Consequently, accelerations arise when the subglacial hydraulic efficiency is insufficient to handle the increased volumes of water arriving at the base, and persist until the drainage system evolves to accommodate the increased discharge.

An important implication of this research is that large pulses of meltwater to the base of an ice sheet may be a critical factor in determining dynamic ice sheet change. In Greenland, one way that this sort of injection of meltwater may occur is via the draining of surface meltwater ponds through cold basal ice (van der Veen, 2007). Das et al. (2008) present a dramatic illustration of this process by capturing the catastrophic drainage of a large ( $\sim 2 \mathrm{~km}$ diameter) supraglacial lake, which emptied in 
less than 1.5 hours and produced a flow rate greater than that of the Niagara Falls. The water, which cut through almost a kilometre of ice, lifted and moved the ice sheet and resulted in a short-lived by substantial increase in the average daily displacement. Thousands of lakes form on the Greenland Ice Sheet (GIS) during the ablation season (Box \& Ski, 2007), and any increase in the frequency, duration or magnitude of pulsed drainage to the bed associated with climate warming may therefore influence GIS dynamics (Bartholomaus et al., 2008; Das et al., 2008).

However, whilst satellite data indicate that during the summer, high melt associated with drainage of supraglacial lakes causes the western flank of the GIS to accelerate by between 50 and $100 \%$, relative changes in the outlet glaciers, such as Jakobshavn Isbræ which has been the focus of particular attention, are actually much smaller and more spatially complex (Joughin et al., 2008). Instead, seasonal speedup is in phase with changes in ice front position which may indicate that backstress from buttressing sea ice is a more significant control on the accelerations of tidewater outlet glaciers. Consequently, Joughin et al. (2008) conclude that whilst increased melting due to warming may influence large areas of the GIS, such as those to the south of Jakobshaven where there are comparatively few outlet glaciers, its effect on the most rapidly flowing ice is more modest and the impacts on the future evolution of the GIS, whilst substantial, are unlikely to be catastrophic. Similarly, whilst van de Wal et al. (2008) report rapid ice velocity responses to meltwater input at the timescale of weeks, annual velocities show little variation, supporting the view that accelerations are transient responses whilst the englacial system reconfigures to deal with changing meltwater volume.

In Antarctica, most land-based ice is believed to be frozen to the bedrock so the potential for meltwater-induced acceleration is reduced. Instead, attention has tended to focus on the fact that the base of much of the West Antarctic Ice Sheet (WAIS) lies below sea level. This makes it potentially sensitive to ice sheet thinning and sea level rise, although recent research questions the extent of this instability (Anderson, 2007). However, the WAIS is situated over a crustal rift that is associated with volcanism (Winberry \& Anandakrishnan, 2004) and several volcanoes protrude through the ice sheet (Wilch et al., 1999). In the event of an eruption, the altered thermal regime may release significant volumes of meltwater into the system, lubricating the bed and increasing the potential for a surge (Vogel, 2008). Subglacial volcanoes therefore have the potential to influence ice dynamics and the stability of the WAIS (Vogel \& Tulaczyk, 2006; Corr \& Vaughan, 2008). New airborne radar data have recently been used to identify a volcano beneath the WAIS from a strong 
reflector interpreted as a tephra layer (Corr \& Vaughan, 2008). Whilst this eruption, which is dated to $207 \mathrm{BC} \pm 240 \mathrm{yrs}$ and correlated with strong conductivity signals detected in ice cores (Hammer et al., 1997; Kurbatov et al., 2006), appears to have had only limited impact on the dynamics of the WAIS, it raises the possibility of more widespread volcanism beneath the WAIS which may be revealed by reinterepreting similar radar data (Vogel, 2008).

Palaeoenvironmental research provides baseline information against which the stability of the modern ice sheets can be assessed. A growing body of sea level data is being collected from the logistically challenging high latitude regions which, when analysed in combination with geophysical models of glacio-isostatic adjustment (GIA), can be used to provide important constraints on the pattern and timing of past ice sheet changes. In southern and southeastern Greenland, marine limit and isolation basin data reveal late glacial and early Holocene RSL falls driven by rapid isostatic rebound (Bennike et al., 2002; Sparrenbom et al., 2006; Long et al., 2008). These new data do not fit well with existing GIA models (e.g. Tarasov \& Peltier, 2002; Huybrechts, 2002; Fleming and Lambeck, 2004), commonly underestimating the height of the marine limit by several tens of metres. These field data may indicate that current models underestimate the extent and thickness of Greenland ice at the Last Glacial Maximum (LGM), and that once melting commenced, it proceeded more rapidly than previously believed (Sparrenbom et al., 2006; Long et al., 2008).

Similar misfits between simulated and reconstructed RSL are evident in data from Antarctica where Bassett et al. (2007) conduct a series of sensitivity analyses to examine the possibility that Antarctic melting is a plausible, dominant source of meltwater pulse (MWP) 1a. They use the "sea-level fingerprinting" approach (see Edwards, 2005) to compare the contrasting patterns of simulated RSL change produced by two end-member scenarios in which all meltwater is supplied from either a northern or southern hemisphere source. Whilst the southern hemisphere scenario performs best, the authors caution that limitations in the available field data preclude a definitive conclusion being drawn. However, neither model produces a reasonable match to field data from half of the study sites examined, under-predicting the isostatic component of RSL change in the Antarctic Peninsula and the Sôya Coast (East Antarctic Ice Sheet). Once again, this suggests that thicker ice may have been present in potential meltwater source regions such as the Antarctic Peninsula (Bentley, 1999; Huybrechts, 2002; Heroy \& Anderson, 2005). However, recent work by Heroy \& Anderson (2007) using marine cores and seismic data seems to indicate that retreat of grounded ice in this area occurred several thousand years earlier than 
the estimates used by current GIA models. Whilst there are substantial challenges associated with establishing a reliable chronology from these data, they may limit the extent to which additional ice can be added in this area. Nevertheless, Heroy \& Anderson (2007) agree that some melting from the Antarctic Peninsula did contribute to both MWP1a and MWP1b, even if the volumes concerned may have been relatively small.

\section{Extreme Events}

Much of the interest in meltwater pulses and ice sheet instability stems from the fact that the can produce rapid rates of sea level rise several times greater than the longer term average. Abrupt but short-lived changes can also be destructive, and coasts are vulnerable to impacts from extreme events that perturb water levels for comparatively brief intervals. For example, it is estimated that 120 million people are at risk from tropical cyclone hazards which killed 250000 people in the last two decades of the $20^{\text {th }}$ century (Nicholls et al., 2007). Tropical cyclone Nargis struck the low-lying Irrawaddy delta in May 2008 with devastating consequences that were reminiscent of the Great Sumatra-Andaman Indian Ocean tsunami of December 2004 (Lay et al., 2005). Over 130000 lives were lost, and a further 1.5 million people severely affected by the flooding, destruction of homes, infrastructure, farms and fisheries (Webster, 2008). Deltas are particularly vulnerable since increases in sea level are compounded by land subsidence and human interference such as sediment trapping by dams (Bird, 2000; Dixon et al., 2006; Ericson et al., 2006; Church et al., 2008). Given a sea level rise of $2 \mathrm{~mm} / \mathrm{yr}$, it is estimated that over 8.5 million people living in deltaic regions will be affected by the middle of this century (Ericson et al., 2006) and this figure will be higher if the incidence of extreme events increases. Whilst these impacts are likely to be greatest in the densely populated Asian megadeltas (Nicholls et al., 2007) the destruction caused by Hurricane Katrina in 2005, which result in over 1800 deaths (Graumann et al., 2005), and economic losses estimated at over 100 billion US dollars (NOAA, 2007), illustrates the general vulnerability of inhabited low-lying areas.

Limitations in instrumental data mean that at present there is still some controversy concerning whether or not intense cyclones are becoming more common (Emanuel, 2005; Webster et al., 2005; Chan, 2006; Mann \& Emanuel, 2006; Landsea et al., 2006; Holland \& Webster, 2007). Elsner et al. (2008) conclude that whilst average trends vary between basins, Atlantic tropical cyclones have increased in strength in recent years. A more widespread increasing trend is noted in the wind speeds of the 
strongest cyclones, which is consistent with the idea that warmer seas will result in more violent storms. However, large uncertainties are associated with recent modelbased investigations of future trajectories of change, with some studies showing a modest decrease in the activity of Atlantic hurricanes during the $21^{\text {st }}$ century (Knutson et al., 2008), whilst others note that the sign and magnitude of predicted changes varies considerably between ocean basins and from model to model (Emanuel et al., 2008).

Palaeoenvironmental records are potential tools for evaluating the risk posed by extreme events since they can be examined to infer longer-term trends in activity during the Holocene (e.g. Liu \& Fearn 1993, 2000; Donnelly et al., 2001a,b). Donnelly \& Woodruff (2007) use coarse sediment layers washed over a coastal barrier into a lagoon to examine hurricane activity in the Caribbean during the last 5000 years. They infer these events have more than local significance by the similarity in timing exhibited between phases of enhanced or reduced storm inputs recorded at the study site, and similar evidence of hurricane landfalls reported from records in Florida and Long Island Sound (Liu \& Fearn, 2000; Scileppi \& Donnelly, 2007). Together these data suggest that the last millennium was a comparatively quiescent period for hurricane activity until around $1700 \mathrm{AD}$ when a more active regime develops. The similarity with proxy records of precipitation leads Donnelly \& Woodruff (2007) to conclude that hurricane variability is probably modulated by atmospheric dynamics associated with ENSO and the West African monsoon, rather than having a simple relationship to sea surface temperature. Systematic changes in site sensitivity through time, such as changes in the morphology of the protective barrier, may distort hurricane intensity records, and so further work is required to see if the temporal patterns revealed are evident in more study sites along the coasts of the Caribbean and USA (Donnelly \& Webb, 2004; Scileppi \& Donnelly, 2007).

Storm deposits can be confused with those associated with tsunamis. Whilst both phenomena may have devastating coastal impacts, it is important to differentiate between their imprints in the geological record if reliable inferences of recurrence and risk are to be made from them. Consequently, a considerable body of literature is now devoted to developing criteria by which such sedimentary deposits may be discriminated (Dawson \& Shi, 2000; Dominey-Howes, 2002; Dominey-Howes et al., 2006; Tappin, 2007; Dawson \& Stewart 2007a, b). Fine-grained, sandy sediments have been the focus of most attention since a combination of data including spatial distribution, sedimentology and microfossil content can be applied to critically evaluate these deposits (e.g. Nanayama et al., 2003; Cisternas et al. 2005; 
Nanayama and Shingeno 2006; Morton et al, 2007; Sawai et al., 2008). Kelletat (2008) contends that this emphasis has been at the expense of coarser deposits which are often overlooked or discounted despite an expanding body of work that employs boulder accumulations as evidence of tsunami deposition (e.g. Scheffers, 2002; Scicchitano et al., 2007; Mastronuzzi et al., 2007; Scheffers \& Scheffers, 2007; Scheffers et al., 2008a,b).

It is possible that coarse material has greater potential for preserving a tsunami imprint, since recent work examining deposits left by the December 2004 tsunami suggests that its geomorphological and sedimentological record appears limited and is likely to be rapidly lost as it is modified by normal marine processes (Keating et al., 2005). However, whilst boulder-based research has great potential, it currently lacks the multiple strands of evidence that assist in developing clear tsunami fingerprints from finer deposits. Often deposit formation is inferred from calculations of boulder mass and the size of wave required to move them (e.g Nott, 2003). However, the equations used to calculate wave height only deal with a subset of possible transport mechanisms, and Spiske et al. (2008) demonstrate that even when these equations are applied, wave heights can be significantly overestimated by failing to accurately measure boulder volume and porosity. On the basis of observations made in the wake of the Indian Ocean tsunami, Paris et al. (2008) conclude that whilst the spatial distribution and position of boulders can provide information on the direction and transport mechanism of tsunamis, at present boulder fields do not appear to be powerful indicators of palaeotsunami magnitude. It is clear that more detailed studies are now required, especially since in some instances, where additional analysis has been undertaken, no support is found for the proposed tsunami origin of deposits (e.g. Dominey-Howes et al., 2006).

\section{Discussion}

The significance of sea level change is self-evident given that human societies are intrinsically linked with the coast. Almost a quarter of the world's population live within $100 \mathrm{~km}$ of the sea (Small \& Nicholls, 2003). Within this relatively thin band, population densities are three times the global average (including 12 of the worlds 16 largest cities, each containing over 10 million inhabitants), and by the 2080s, the coastal population may reach in excess of 5 billion people (Nicholls et al., 2007).

Despite this significance, the uncertainties attached to projections of future sea level rise remain comparatively large, and there are some indications that the AR4 estimates may be somewhat conservative based on evidence from recent trends 
(Rahmstorf, 2007a; Jevrejeva et al., 2008). Whilst the potential for rapid rises of several metres during the $21^{\text {st }}$ century has been raised (Otto-Bleisner et al., 2006; Overpeck et al., 2006; Hansen et al., 2007), a recent study that considers the possible upper limits of land-ice contributions concludes that rises in excess of 2 metres by 2100 are physically impossible on glaciological grounds (Pfeffer et al., 2008). Instead, Pfeffer et al. (2008) suggest that $0.8-2.0 \mathrm{~m}$ of sea level rise during the $21^{\text {st }}$ century is a plausible initial estimate that includes the influence of increased ice dynamics.

Further work is required to balance the sea level budget through improved observations of recent sea level change and better quantification of the factors contributing to it. In addition to thermal expansion and the role of ice sheets outlined above, the contributions from other sources such as glaciers and ice caps are also significant areas for study (Lemke et al., 2007; Meier et al., 2007; Pfeffer et al., 2008). Changes in terrestrial storage are an often overlooked and poorly quantified factor, but one that recent research suggests may have important implications for understanding $20^{\text {th }}$ century sea level change. Chao et al. (2008) estimate that during the past half-century, dam building has been responsible for impounding increased volumes of freshwater, equivalent to $0.55 \mathrm{~mm} /$ year of sea level rise. If correct, this could indicate that some of the variations in rates of sea level rise noted from tide gauges may reflect "artificial" rather than "natural" processes. Whilst this reduction may be offset by increased supply from underground sources, the magnitude of such inputs is largely unknown (Huntington, 2008).

Improvements in instrumental data, such as those provided by the expanding network of tide gauges under the Global Sea Level Observing System programme (http://www.gloss-sealevel.org/); the recently achieved global (ice-free) ocean coverage of Argo floats (http://www.argo.net); and the latest generation of satellite platforms such as the Gravity Recovery and Climate Experiment (GRACE) (http://www.csr.utexas.edu/grace/), and the new Gravity field and steady-state Ocean Circulation Explorer (GOCE) mission (http://www.esa.int/SPECIALS/GOCE/); will be key to advancing our understanding of sea level change in the $21^{\text {st }}$ century. As the quality of observing systems improves, new opportunities for investigation will arise, such as the potential to examine changing terrestrial surface water levels or sea levels associated with oceanic mesoscale variability (Alsdorf et al., 2007; Church et al., 2008).

The GIA signal is a critical element in decoding ice sheet mass change from GRACE data, since postglacial rebound is the largest source of uncertainty in areas such as 
the East Antarctic Ice Sheet (Velicogna \& Wahr, 2006). New RSL data from high latitude studies have an important role to play in refining mdoels of GIA, as do similar studies from formerly glaciated areas. Interestingly, several recent papers seem to require larger, more extensive ice sheets than previously thought, and indicate that these then melted away rapidly during the early stages of deglaciation (Bassett et al., 2007; Brooks et al., 2008; Long et al., 2008). In some instances, significant misfits remain between field data and model simulations and this has led some to suggest that the current generation of models fail to reproduce the rate and magnitude of RSL change immediately following deglaciation (McCabe, 1997; Cooper et al., 2002; Kelley et al., 2006; McCabe et al., 2007; McCabe 2008a, 2008b). Alternatively, some of these misfits may be associated with the limited precision of available sea level data, resulting in erroneous RSL reconstructions (Edwards et al., 2008). In either event, further work is required to continue to refine GIA model simulations which play a critical role in interpreting the spatial patterns of sea level change, and in converting global-scale projections of future sea level rise into ranges that are appropriate at regional or local scales.

In the UK, IPCC projections are tailored for regional use as part of the UK Climate Impact Programme (UKCIP). This process is underpinned by RSL data collected by numerous Earth scientists and summarised most recently by Shennan \& Horton (2002) in their map of RSL change. UKCIP use this map to adjust IPCC projections by accounting for differential vertical land movements related to ongoing GIA. However, this approach implicitly assumes that no significant sea level change has taken place during the last 4000 years and, whilst changes during this interval are poorly quantified, instrumental records indicate this assumption is invalid for at least the last century (Gehrels \& Long, 2008). New sea level data will continue to refine the patterns and rates of RSL change (e.g. Massey et al., 2008) and UKCIP projections will need to be updated to account for these advances in understanding. Whilst these estimates provide an indication of the chronic effects of sea level rise, the impacts of any associated change in extreme events must also be considered (e.g. Woodworth et al., 2007) since these often have dramatic impacts on coastal environments.

In addition to projections of future sea level rise, practitioners require much better information on precisely how quoted figures will translate into tangible effects in their area, such as shoreline retreat, erosion and flooding (Tribbia \& Moser, 2008). The complex nature of dynamic coastal systems means they often exhibit non-linear responses to change, characterised by sensitivity to critical thresholds relating to rates of sea level rise and sediment supply (Dronkers, 2005). Consequently, whilst 
coastlines may continually adjust towards a dynamic equilibrium (Woodroffe, 2003), this process is commonly punctuated rather than progressive, and may also deviate abruptly and significantly (although sometimes more ephemerally) to extreme events. As a result, the relationship between sea level rise and coastal response is difficult to quantify (Cowell et al., 2006), and extrapolation of past rates to infer future erosion trends is unreliable (Nicholls \& Stive, 2004). This situation is compounded by human modification of coastal and estuarine environments which has become increasingly profound in recent centuries (Lotze et al., 2006).

The Louisiana coast, incorporating the Mississippi delta, illustrates the challenges associated with vulnerable deltaic plains. Since the 1970s, $90 \%$ of the Louisiana shoreline has been eroding at an average rate of $12.0 \mathrm{~m} / \mathrm{yr}$ (Morton et al., 2004), whilst over $1500 \mathrm{~km}^{2}$ of coastal wetland were transformed into open water between 1978 and 2000 due to the combined effects of sediment starvation, increased salinity and water level (Barras et al., 2003). Superimposed upon this backdrop of progressive change are the impacts of extreme events such as Hurricane Katrina which resulted in the loss of an estimated $388 \mathrm{~km}^{2}$ of land in the Mississippi delta area (Barras, 2006), and the destruction of around $50 \%$ of the Chandeleur Islands, south-east of New Orleans (Nicholls et al., 2007). The complexity of coastal processes is illustrated by the fact that whilst sediment starvation due to flood protection measures may contribute to wetland loss in the Mississippi delta, Turner et al. $(2006,2007)$ contend sediment deposition by hurricanes is the most significant supplier of inorganic material to landward areas where fluvial inputs are intermittent. Whilst their calculations have been criticised (Törnqvist et al., 2007), these results may indicate that although hurricanes are most commonly associated with destructive impacts, they may in fact play an important role in promoting wetland growth and stability in the face of rising RSL. If correct, this may indicate that the organic component of the wetland ecosystem is the key to understanding its longerterm health.

The importance of organic coastal sediments is further highlighted by palaeoenvironmental studies that reveal longer-term changes relating to processes such as sediment compaction. Despite the complexity of establishing reliable sediment chronologies in deltas due to sediment storage and remobilisation (Stanley and Hait, 2000), careful analysis of basal peat can produce relatively precise records of RSL change which permit inferences about longer-term stability to be made (e.g. Törnqvist et al., 2004a,b, 2006). Gonzalez \& Törnqvist (2006) and Törnqvist et al. (2006) use RSL data from coastal Louisiana to examine the stability of the 
Mississippi delta area, concluding that subsidence and wetland loss is likely to be due to the compaction of Holocene sediments. Whilst this assertion is contested (Blum et al., 2008; Donnelly \& Giosan, 2008) the concept of sediment compaction as a driver of coastal change is not restricted to the Mississippi delta. Long et al. (2006) examine the late Holocene sediments of Romney Marsh in southern Britain, and propose that sediment surface lowering due to compaction was a critical process that effectively resulted in the "self-destruction" of wetlands via dewatering, desiccation and loading by tidal water and clastic sediments. These internal controls on coastal evolution highlight the problems of inferring RSL oscillations on the basis of interchanges between organic and minerogenic sequences. This is particularly problematic when attempting to correlate similar sequences across large geographical areas since this requires assumptions of stability that may be erroneous (e.g. Behre, 2007; Vink et al., 2007).

\section{Concluding Remarks}

Sea level research encapsulates the aims of IYPE by bringing together Earth scientists from a wide range of disciplines, and combining their knowledge to address an issue with direct consequences for society. The ocean has a long 'memory' which means our actions today will have repercussions that extend several centuries into the future (Meehl et al., 2005). Similarly, in order to fully understand modern sea level, it is necessary to peer backward in time and piece together the sequence of events leading up to the present. Geologically based reconstructions of past RSL provide one means of achieving this, and associated palaeoenvironmental information can provide evidence of coastal response to these changes. In some cases, this information can even be used to examine possible human responses to environmental change (e.g. Turney \& Brown, 2007; Chen et al., in press).

Producing new information is not the entire story however, since an apparent disconnect exists between science and decision making which results in many management decisions being made without significant scientific input (Sarewitz and Pielke, 2007). Tribbia \& Moser (2008) note that scientists often publish in areas that are not commonly read by decision makers, whilst many managers have insufficient time, resources or expertise to analyse and assess all the new information that is produced. This situation is exacerbated where scientists fail to produce the kinds of information that managers require (McNie, 2007), and when managers turn to the media leaving valuable academic resources untapped (Tribbia \& Moser, 2008). 
Whilst palaeoenvironmental studies can produce models of long-term coastal evolution covering several thousands of years (e.g. Long et al., 2000; Allen, 2003, 2005), coastal managers face the challenge of interpreting these in light of projections of future sea level rise and contemporary process studies that commonly cover timescales of a few years of less (Rodriguez et al., 2001; Storms et al., 2002; Stolper et al., 2005; Nicholls et al., 2007). Similarly, improved estimates of sea level rise are not easily translated into key parameters such as erosion and coastal retreat. Simplistic models, such as the Bruun rule, are increasingly regarded as being inadequate due to their inability to capture important feedback processes (Cooper \& Pilkey, 2004; Stive, 2004). Process-based numerical models developed for particular shoreline types offer an alternative (e.g. Walkden \& Dickson, 2008), but are not applicable in all cases.

Whilst it is important that academic research is not simply reduced to the status of a service-provider for decision makers, it is clear that improved communication and closer co-operation between actors is important if society is to make maximum use of scientific knowledge. One possible means by which this may be achieved is through the use of "boundary organisations" which mediate in the "co-production of knowledge" that is of greater utility to a wider audience (Guston, 2001). Geographers are particularly well qualified to act as translators between the scientific and social arenas, and partnerships between science, government, business and community sectors will be critical in addressing sea level rise and its impacts during the $21^{\text {st }}$ century (Church et al., 2008).

\section{Acknowledgements}

I am extremely grateful to the many colleagues who have taken time over the last four years to send me reprints and preprints of their work. I would also like to acknowledge the contribution made by the constructive discussions and informative meetings that have taken place as part of IGCP 495 "Quaternary Land-Ocean Interactions: Driving Mechanisms and Coastal Responses". Finally, a special thanks to Hazel Edwards who was born in the middle of writing this paper and has displayed remarkable tolerance for being winded whilst suspended over a laptop computer. 


\section{References}

Allen, J.R.L., 2003: An eclectic morphostratigraphic model for the sedimentary response to Holocene sea-level rise in northwest Europe. Sedimentary Geology 161, 31-54. doi: 10.1016/S0037-0738(02)00394-9

Allen, J.R.L., 2005: Teleconnections and their archaeological implications, Severn Estuary Levels and the wider region: the 'fourth' and other mid-Holocene peats Archaeology in the Severn Estuary 16, 17-65.

Alsdorf D.E., Rodriguez E., Lettenmaier D.P., 2007: Measuring surface water from space. Reviews of Geophysics 45, RG2002. doi:10.1029/2006RG000197

Anderson, J.B., 2007: Climate change: Ice Sheet Stability and Sea-Level Rise. Science 315, 1803-1804. doi: 10.1126/science.1140766

Baines, P.G., Folland, C.K., 2007: Evidence for a rapid global climate shift across the late 1960s. Journal of Climate 20, 2721-2744. doi: 10.1175/JCLI4177.1.

Barnett, T.P., 1984: The estimation of "global" sea level change: a problem of uniqueness. Journal of Geophysical Research 89, 7980-7988.

Barras, J.A., 2006: Land area change in coastal Louisiana after the 2005 hurricanes-a series of three maps U.S. Geological Survey Open-File Report 061274.

Barras, J., Beville, S., Britsch, D., Hartley, S., Hawes, S., Johnston, J., Kemp, P., Kinler, Q., Martucci, A., Porthouse, J., Reed, D., Roy, K., Sapkota, S., Suhayda, J., 2003: Historical and projected coastal Louisiana land changes: 1978-2050 U.S. Geological Survey Open File Report 03-334,

Bartholomaus, T.C., Anderson, R.S., Anderson, S.P., 2008: Response of glacier basal motion to transient water storage Nature Geoscience 1, 33-37. doi:10.1038/ngeo.2007.52

Bassett, S.E., Milne, G.A., Bentley, M.J., Huybrechts, P., 2007: Modelling Antarctic sea-level data to explore the possibility of a dominant Antarctic contribution to meltwater pulse la Quaternary Science Reviews, 26, 2113-2127. doi:10.1016/j.quascirev.2007.06.011

Behre, K.,-E., 2007: A new Holocene sea-level curve for the southern North Sea Boreas 36, 82-102. doi: 10.1080/03009480600923386 
Bennike, O., Björck, S., Lambeck, K., 2002: Estimates of South Greenland lateglacial ice limits from a new relative sea-level curve. Earth and Planetary Science Letters 197, 171-186. doi: 10.1016/S0012-821X(02)00478-8.

Bentley, M.J., 1999: Volume of Antarctic ice at the last glacial maximum, and its impact on global sea level change Quaternary Science Reviews 18, 1569-1595. doi:10.1016/S0277-3791(98)00118-8.

Bindoff, N.L., Willebrand, J., Artale, V., Cazenave, A, Gregory, J., Gulev, S., Hanawa, K., Le Quéré, C., Levitus, S., Nojiri, Y., Shum, C.K., Talley, L.D., and Unnikrishnan, A., 2007: Observations: Oceanic Climate Change and Sea Level. In: Climate Change 2007: The Physical Science Basis. Contribution of Working Group I to the Fourth Assessment Report of the Intergovernmental Panel on Climate Change [Solomon, S., D. Qin, M. Manning, Z. Chen, M. Marquis, K.B. Averyt, M. Tignor and H.L. Miller (eds.)]. Cambridge University Press, Cambridge, United Kingdom and New York, NY, USA.

Bird, E.C.F., 2000: Coastal Geomorphology: An Introduction. Wiley and Sons, Chichester. $340 \mathrm{pp}$.

Blum M.D., Tomkin J.H., Purcell A., Lancaster R.R., 2008: Ups and downs of the Mississippi Delta Geology 36, 675-678. doi: 10.1130/G24728A.1

Box, J.E., Ski, K., 2007: Remote sounding of Greenland supraglacial melt lakes: implications for subglacial hydraulics Journal of Glaciology 53, 257-265. doi: $10.3189 / 172756507782202883$

Brooks, A.J., Bradley, S.L., Edwards, R.J., Milne, G.A., Horton, B.P., Shennan, I., 2008: Post-Glacial Relative Sea-Level Observations from Ireland and their Role in Glacial Rebound Modelling Journal of Quaternary Science 23(2), 175-192. doi: 10.1002/jqs.1119

Chan, J.C.L., 2006: Comments on "Changes in tropical cyclone number, duration, and intensity in a warming environment." Science $311,1713$. doi: 10.1126/science.1121522.

Chao, B.F., Wu, Y.H., Li, Y.S., 2008: Impact of Artificial Reservoir Water Impoundment on Global Sea Level Science 320, 212-214. doi: 10.1126/science. 1154580 . 
Chen, Z., Zong, Y., Wang, Z., Wang, H., Chen, J., 2008: Migration patterns of Neolithic settlements on the abandoned Yellow and Yangtze River deltas of China. Quaternary Research 70, 301-314. doi:10.1016/j.yqres.2008.03.011.

Church, J.A., White, N.J., 2006: A $20^{\text {th }}$ century acceleration in global sea-level rise. Geophysical Research Letters 33, L01602. doi:10.1029/2005GL024826.

Church, J.A., White, N.J., Arblaster, J.M. 2005: Significant decadal-scale impact of volcanic eruptions on sea level and ocean heat content. Nature 438, 74-77. doi:10.1038/nature04237

Church, J.A., White, N.J., Aarup, T., Wilson, W.S., Woodworth, P.L., Domingues, C.M., Hunter, J.R., Lambeck, K., 2008: Understanding global sea levels: past, present and future Sustainability Science 3(1), 1-167. doi:10.1007/s11625-008-00424

Cisternas, M., Atwater, B.F., Torrejón, F., Sawai, Y., Machuca, G., Lagos, M., Eipert, A., Youlton, C., Salgado, I., Kamataki, T., Shishikura, M., Rajendran, C.P., Malik, J.K., Rizal, Y., Husni, M. 2005: Predecessors of the giant 1960 Chile earthquake Nature 437, 404-407. doi:10.1038/nature03943.

Cooper, J.A.G., Pilkey, O.H., 2004: Sea-level rise and shoreline retreat: time to abandon the Bruun Rule. Global and Planetary Change 43, 157-171. doi:10.1016/j.gloplacha.2004.07.001

Cooper J.A.G., Kelley J.T., Belknap D.F., Quinn R., McKenna J., 2002: Inner shelf seismic stratigraphy off the north coast of Northern Ireland: new data on the depth of the Holocene lowstand. Marine Geology 186, 369-387. doi: 10.1016/S00253227(02)00311-0.

Corr, H.F.J., Vaughan, D.G., 2008: A recent volcanic eruption beneath the West Antarctic ice sheet Nature Geoscience 1, 122-125. doi:10.1038/ngeo106.

Cowell, P.J., Thom, B.G., Jones, R.A., Everts C.H., Simanovic, D., 2006: Management of uncertainty in predicting climate-change impacts on beaches Journal of Coastal Research 22, 232.

Das, S.B., Joughin, I., Behn, M.D., Howat, I.M., King, M.A., Lizarralde, D., Bhatia, M.P., 2008: Fracture propagation to the base of the Greenland Ice Sheet during supraglacial lake drainage Science $320,778-781$. doi: 10.1126/science.1153360 
Dawson, A.G., Shi, S., 2000: Tsunami deposits. Pure and Applied Geophysics 157, 875-897. doi: 10.1007/s000240050010.

Dawson, A., Stewart, I., 2007a: Tsunami geoscience Progress in Physical Geography 31, 575-590. doi: 10.1177/0309133307087083

Dawson, A.G., Stewart, I., 2007b: Tsunami deposits in the geological record. Sedimentary Geology 200, 166-183. doi: 10.1016/j.sedgeo.2007.01.002.

Delworth, T.L., Mann, M.E., 2000: Observed and simulated multidecadal variability in the Northern Hemisphere. Climate Dynamics 16, 661-676.

Dijkstra, H.A., Ghil, M., 2005: Low-frequency variability of the large-scale ocean circulation: A dynamical systems approach Reviews of Geophysics 43, RG3002. doi:10.1029/2002RG000122.

Dixon, T.H., Amelung, F., Ferretti, A., Novali, F., Rocca, F., Dokka, R., Sella, G., Kim, S.- W., Wdowinski, S., Whitman, D., 2006: Space geodesy: Subsidence and flooding in New Orleans. Nature 441, 587-588. doi:10.1038/441587a

Dominey-Howes, D., 2002: Documentary and geological records of tsunamis in the Aegean Sea region of Greece and their potential value to risk assessment and disaster management Natural Hazards 25, 195-124. doi:10.1023/A:1014808804611.

Dominey-Howes, D.T.M., Humphreys, G.S., Hesse, P.P., 2006: Tsunami and palaeotsunami depositional signatures and their potential value in understanding the late-Holocene tsunami record The Holocene 16, 1095-1107 doi: 10.1177/0959683606069400

Domingues, C.M., Church, J.A., White, N.J., Gleckler, P.J., Wijffels, S.E., Barker, P.M., Dunn, J.R., 2008: Improved estimates of upper-ocean warming and multidecadal sea-level rise Nature 453, 1090-1093. doi:10.1038/nature07080

Donnelly, J.P., Webb III, T., 2004: Backbarrier sedimentary records of intense hurricane landfalls in the northeastern United States. In: Hurricanes and Typhoons: Past, Present, and Potential [Murnane, R., Liu, K., (eds)] Columbia University Press, New York.

Donnelly, J.P., Woodruff, D., 2007: Intense hurricane activity over the past 5,000 years controlled by El Niño and the west African monsoon Nature 447, 465-468. doi:10.1038/nature05834

Donnelly, J.P., Giosan, L., 2008: Tempestuous highs and lows in the Gulf of Mexico. Geology 36, 751-752. doi: 10.1130/focus092008.1 
Donnelly, J.P., Roll, S., Wengren, M., Butler, J., Webb III, T., 2001a: Sedimentary evidence of intense hurricane strikes from New Jersey Geology 29, 615-618. DOI: 10.1130/0091-7613(2001)029<0615:SEOIHS>2.0.CO;2

Donnelly, J.P., Bryant, S.S., Butler, J., Dowling, J., Fan, L., Hausmann, N., Newby, P., Shuman, B., Stern, J., Westover, K., Webb, III, T., 2001b: 700 yr sedimentary record of intense hurricane landfalls in southern New England Geological Society of America Bulletin 113, 714-727. doi: 10.1130/00167606(2001)113<0714:YSROIH>2.0.CO;2

Dronkers, J., 2005: Dynamics of Coastal Systems. Advanced Series on Ocean Engineering 25. World Scientific Publishing Company, Hackensack, 519 pp.

Edwards, R.J., 2005: Sea Levels: Abrupt Events and Mechanisms of Change. Progress in Physical Geography 29, 599-608. doi: 10.1191/0309133305pp465pr

Edwards, R.J., 2007: Sea Levels: Resolution and Uncertainty Progress in Physical Geography 31, 621-632. doi: 10.1177/0309133307087086.

Edwards, R.J., Brooks, A.J., Shennan, I., Milne, G. Bradley, S., 2008: Reply: Postglacial relative sea-level observations from Ireland and their role in glacial rebound modelling Journal of Quaternary Science doi: 10.1002/jqs.1162

Elsner, J.B., Kossin, J.P., Jagger, T.H., 2008: The increasing intensity of the strongest tropical cyclones. Nature 455, 92-95. doi:10.1038/nature07234

Emanuel, K.A., 2005: Increasing destructiveness of tropical cyclones over the past 30 years Nature 436, 686-688. doi:10.1038/nature03906

Emanuel, K., Sundararajan, R., Williams, J., 2008: Hurricanes and global warming: results from downscaling IPCC AR4 simulations Bulletin of the American Meteorological Society 89, 347-367. doi: 10.1175/BAMS-89-3-347.

Ericson, J.P., Vorosmarty, C.J., Dingman, S.L., Ward, L.G., Meybeck, M., 2006: Effective sea-level rise and deltas: causes of change and human dimension implications Global Planet Change 50, 63-82.

Fleming, K., Lambeck, K., 2004. Constraints on the Greenland Ice Sheet since the Last Glacial Maximum from sea-level observations and glacial-rebound models Quaternary Science Reviews 23, 1053-1077. doi:10.1016/j.quascirev.2003.11.001. 
Gehrels, W.R., Long, A.J., 2008: Sea level is not level. The case for a new approach to predicting UK sea-level rise. Geography 93, 11-16.

Gehrels, W.R., Hayward, B.W., Newnham, R.M., Southall, K.E., 2008: A 20th Century acceleration of sea-level rise in New Zealand Geophysical Research Letters 35, L02717. doi:10.1029/2007gl032632.

Gleckler, P.J., AchutaRao, K.M., Gregory, J.M., Santer, B.D., Taylor, K.E., Wigley, T.M.L., 2006a: Krakatoa lives: the effect of volcanic eruptions on ocean heat content and thermal expansion Geophysical Research Letters 33, L17702. doi:10.1029/2006GL026771

Gleckler, P.J., Wigley, T.M.L., Santer, B.D., Gregory, J.M., AchutaRao, K.M., Taylor, K.E., 2006b: Volcanoes and climate: Krakatoa's signature persists in the ocean Nature 439, 675. doi:10.1038/439675a.

González, J.L., Törnqvist, T.E., 2006: Coastal Louisiana in Crisis: Subsidence or Sea Level Rise? Eos 87, 493-498.

Goodsite, M.E., Rom, W., Heinemeier, J., Lange, T., Ooi, S., Appleby, P.G., Shotyk, W., van der Knaap, W.O., Lohse, C., Hansen, T.S., 2001: High resolution AMS $14 \mathrm{C}$ dating of post-bomb peat archives of atmospheric pollutants Radiocarbon 43 (2B), 495-515.

Goodwin, I.D., Harvey, N., 2008: Subtropical sea-level history from coral microatolls in the southern Cook Islands, since 300 AD Marine Geology 253, 14-25 doi:10.1016/j.margeo.2008.04.012

Gouretski V., Koltermann, K.P., 2007: How much is the ocean really warming? Geophysical Research Letters 34, L01610. doi:10.1029/2006GL027834

Graumann, A., Houston, T., Lawrimore, J., Levinson, D., Lott, N., McCown, S., Stephens, S., Wuertz, D., 2005: Hurricane Katrina - a climatological perpective. NOAA National Climate Data Center Technical Report 2005-01.

Guston, D.H., 2001: Boundary organizations in environmental policy and science: an introduction. Science Technology and Human Values 26 (4), 399-408.

Gutenberg, B., 1941: Changes in sea level, postglacial uplift, and mobility of the earth's interior Bulletin of the Geological Society of America 52, 721-772.

Hammer, C.U., Clausen, H.B., Langway, C.C., 1997: 50,000 years of recorded global volcanism Climate Change 35, 1-15. doi: 10.1023/A:1005344225434. 
Hansen, J., Sato, M., Kharecha, P., Russell, G., Lea, D.W., Siddall, M., 2007: Climate change and trace gases. Philosophical Transactions of the Royal Society A, 365, 1925-1954. doi:10.1098/rsta.2007.2052

Harvey, M.M., Hansom, J.D., MacKenzie, A.B., 2007: Constraints on the use of anthropogenic radionuclide-derived chronologies for saltmarsh sediments Journal of Environmental Radioactivity 95, 126-148. doi:10.1016/j.jenvrad.2007.02.005.

Heroy, D.C., Anderson, J.B., 2005: Ice sheet extent of the Antarctic Peninsula region during the last glacial maximum (LGM) -insights from glacial geomorphology Geological Society of America Bulletin 117, 1497-1512. doi: 10.1130/B25694.1.u

Heroy, D.C., Anderson, J.B., 2007: Radiocarbon constraints on Antarctic Peninsula ice sheet retreat following the Last Glacial Maximum (LGM) Quaternary Science Reviews 26, 3286-3297. doi:10.1016/j.quascirev.2007.07.012

Holgate, S. J., Woodworth, P.L, 2004: Evidence for enhanced coastal sea level rise during the 1990s. Geophysical Research Letters 31, L07305. doi:10.1029/2004GL019626.

Holgate, S. J., Jevrejeva, S., Woodworth, P.L, Brewer, S., 2007: Comment on "A Semi-Empirical Approach to Projecting Future Sea-Level Rise" Science 317, 1866 doi: $10.1126 /$ science. 1140942

Holland, G.J., Webster, P.J., 2007: Heightened tropical cyclone activity in the North Atlantic: natural variability or climate trend? Philosophical Transactions of the Royal Society A 365, 2695-2716. doi:10.1098/rsta.2007.2083.

Huntington, T.D., 2008. Can we dismiss the effect of changes in land-based water storage on sea-level rise? Hydrological Processes 22, 717-723. doi:10.1002/hyp.7001.

Huybrechts, P., 2002: Sea-level changes at the LGM from ice-dynamic reconstructions of the Greenland and Antarctic ice sheets during the glacial cycles Quaternary Science Reviews 21, 203-231. doi:10.1016/S0277-3791(01)00082-8.

Jevrejeva, S., Moore, J.C., Woodworth, P.L., Grinsted, A., 2005: Influence of large scale atmospheric circulation on the European sea level: Results based on the wavelet transform method Tellus $A$ 57, 183-193. doi: 10.1111/j.16000870.2005.00090.x 
Jevrejeva, S., Grinsted, A., Moore, J.C., Holgate, S., 2006: Nonlinear trends and multiyear cycles in sea level records Journal of Geophysical Research 111, C09012. doi:10.1029/2005jc003229.

Jevrejeva, S., Moore, J.C., Grinsted, A., Woodworth, P.L., 2008: Recent global sea level acceleration started over 200 years ago? Geophysical Research Letters 35, L08715. doi:10.1029/2008gl033611.

Joughin, I., Abdalati, A., Fahnestock, M., 2004: Large fluctuations in speed on Greenland's Jakobshavn Isbræ glacier Nature 432, 608-610. doi:10.1038/nature03130.

Joughin, I., Das, S.B., King, M.A., Smith, B.E., Howat, I.M., Moon, T., 2008: Seasonal speedup along the western flank of the Greenland Ice Sheet Science 320, 781-783. doi:10.1126/science. 1153288

Keating, B., Helsley, C., Wafreed, Z., Dominey-Howes, D., 2005: 2004 Indian Ocean tsunami on the Maldives islands, Initial observations. Science of Tsunami Hazards 23, 19-70.

Kelletat, D., 2008: Comments to Dawson, A.G. and Stewart, I. (2007), tsunami deposits in the geological record. - Sedimentary Geology 200, 166-183 Sedimentary Geology, In Press, Accepted Manuscript, Available online 26 March 2008 doi:10.1016/j.sedgeo.2008.03.002

Kelley J.T., Cooper J.A.G., Jackson D.W.T., Belknap D.F., Quinn R.J., 2006: Sealevel change and inner shelf stratigraphy off Northern Ireland. Marine Geology 232(12): 1-15. doi:10.1016/j.margeo.2006.04.002.

Knight, J.R., Allan, R.J., Folland, C.K., Vellinga, M., Mann, M.E., 2005: A signature of persistent natural thermohaline circulation cycles in observed climate Geophysical Research Letters 32, L20708, doi:10.1029/2005GL024233.

Knutson, T.R., Sirutis, J.J., Garner, S.T., Vecchi, G.A., Held, I.M., 2008: Simulated reduction in Atlantic hurricane frequency under twenty-first century warming conditions Nature Geoscience 1, 359 - 364. doi: 10.1038/ngeo202.

Kurbatov, A.V., Zielinski, G.A., Dunbar, N.W., Mayewski, P.A., Meyerson, E.A., Sneed, S.B., Taylor, K.C., 2006: A 12,000 year record of explosive volcanism in the Siple Dome Ice Core, West Antarctica Journal of Geophysical Research 111, D12307. doi:10.1029/2005JD006072. 
Landsea, C.W., Harper, B.A., Hoarau, K., Knaff, J.A., 2006: Can we detect trends in extreme tropical cyclones? Science 313, 452-454. doi: 10.1126/science.1128448.

Lay, T., Kanamori, H., Ammon, C.J., Nettles, M., Ward, S.N., Aster, R.C., Beck, S.L., Bilek, S.L., Brudzinski, M.R., Butler, R., DeShon, H.R., Ekström, G., Satake, K., Sipkin, S., 2005: The Great Sumatra-Andaman Earthquake of 26 December 2004 Science 308, 1127-1133. doi: 10.1126/science.1112250.

Lemke P., Ren J., Alley R., Allison I., Carrasco J., Flato G., Fujii Y., Kaser G., Mote P., Thomas R., Zhang T., 2007: Chapter 4: Observations: changes in snow, ice and frozen ground. In: Solomon S., Qin D., Manning M., Chen Z., Marquis M.C., Averyt K., Tignor M., Miller H.L. (eds.) Climate change 2007: the physical science basis. Contribution of working group 1 to the fourth assessment report of the intergovernmental panel on climate change. Intergovernmental panel on climate change, Cambridge University Press, Cambridge

Liu, K.-B., Fearn, M.L., 1993: Lake-sediment record of late Holocene hurricane activities from coastal Alabama Geology 21, 793-796.

Liu, K.-B., Fearn, M.L., 2000: Reconstruction of prehistoric landfall frequencies of catastrophic hurricanes in northwestern Florida from lake sediment records. Quaternary Research 54: 238-245. doi:10.1006/qres.2000.2166.

Long A.J., Scaife R.G., Edwards R.J., 2000: Stratigraphic architecture, relative sealevel, and models of estuary development in southern England: New data from Southampton Water. In: Pye, K. and Allen, J.R.L. (eds.) Coastal and Estuarine Environments: sedimentology, geomorphology and geoarchaeology. Geological Society, London, Special Publications, 175, 253-279.

Long, A.J., Waller, M.P., Stupples, P., 2006: Driving mechanisms of coastal change: Peat compaction and the destruction of late Holocene coastal wetlands. Marine Geology 225, 63-84. doi:10.1016/j.margeo.2005.09.004.

Long, A.J., Roberts, D.H., Simpson, M.J.R., Dawson, S., Milne, G.A., Huybrechts, P., 2008: Late Weichselian relative sea-level changes and ice sheet history in southeast Greenland Earth and Planetary Science Letters, In Press, Corrected Proof, Available online 9 April 2008 doi:10.1016/j.epsl.2008.03.042

Lotze, H.K., Lenihan, H.S., Bourque, B.J., Bradbury, R.H., Cooke, R.G., Kay, M.C., Kidwell, S.M., Kirby, M.X., Peterson, C.H., Jackson, J.B.C., 2006: Depletion, 
degradation and recovery potential of estuaries and coastal seas Science 312, 18061809.

Mann, M., Emanuel, K. 2006: Atlantic hurricane trends linked to climate change. Eos 87, 233-241.

Marshall, W.A., Gehrels, W.R., Garnett, M.H., Freeman, A.P.H.T., Maden, C., Xu, S., 2007: The use of 'bomb spike' calibration and high-precision AMS ${ }^{14} \mathrm{C}$ analyses to date salt-marsh sediments deposited during the past three centuries Quaternary Research 68, 325-337. doi:10.1016/j.yqres.2007.07.005

Massey, A.C., Gehrels, W.R., Charman, D.J., Milne, G.A., Peltier, W.R., Lambeck, K., Selby, K.A., 2008: Relative sea-level change and postglacial iosostatic adjustment along the coast of south Devon, United Kingdom. Journal of Quaternary Science 23, 415-433. doi: 10.1002/jqs.1149.

Mastronuzzi, G., Pignatelli, C., Sansò, P., Selleri, G., 2007: Boulder accumulations produced by the 20th of February, 1743 tsunami along the coast of southeastern Salento (Apulia region, Italy) Marine Geology 242, 191-205. doi:10.1016/j.margeo.2006.10.025

McCabe A.M., 1997: Geological constraints on geophysical models of RSL change during deglaciation of the West Irish Sea Basin. Journal of the Geological Society of London 154, 601-604.

McCabe, A.M., 2008a: Glacial geology and geomorphology: the landscapes of Ireland. Dunedin Academic Press, Edinburgh, Scotland.

McCabe, A.M., 2008b: Comment: Postglacial relative sea-level observations from Ireland and their role in glacial rebound modelling. A. J. Brooks, S. L. Bradley, R. J. Edwards, G. A. Milne, B. Horton and I. Shennan (2008). Journal of Quaternary Science 23: 175-192. doi: 10.1002/jqs.1163

McCabe A.M., Cooper J.A.G., Kelley J.T., 2007: Relative sea level change from NE Ireland during the last glacial termination. Journal of the Geological Society of London 164,1059-1063.

McGee, E.J., Gallagher, D., Mitchell, P.I., Baillie, M., Brown, D., Keogh, M., 2004: Recent chronologies for tree rings and terrestrial archives using ${ }^{14} \mathrm{C}$ bomb fallout history. Geochimica et Cosmochimica Acta 68, 2509-2516. 
McNie, E.C., 2007: Reconciling the supply of scientific information with user demands: an analysis of the problem and review of the literature. Environmental Science and Policy 10, 17-38. doi:10.1016/j.envsci.2006.10.004.

Meehl, G.A., Washington, W.M., Collins, W.D., Arblaster, J.M., Hu, A., Buja, L.E., Strand, W.G., and Teng, H. 2005: How much more global warming and sea level rise? Science 307, 1769-1772. doi: 10.1126/science.1106663

Meehl, G.A., Stocker, T.F., Collins, W.D., Friedlingstein, P., Gaye, A.T., Gregory, J.M., Kitoh, A., Knutti, R., Murphy, J.M., Noda, A., Raper, S.C.B., Watterson, I.G., Weaver, A.J., and Zhao, Z.-C., 2007: Global Climate Projections. In: Climate Change 2007: The Physical Science Basis. Contribution of Working Group I to the Fourth Assessment Report of the Intergovernmental Panel on Climate Change [Solomon, S., D. Qin, M. Manning, Z. Chen, M. Marquis, K.B. Averyt, M. Tignor and H.L. Miller (eds.)]. Cambridge University Press, Cambridge, United Kingdom and New York, NY, USA.

Meier, M.F., Dyurgerov, M.B., Rick, U.K., O'Neel, S., Pfeffer W.T., Anderson R.S., Anderson, S.P., Glazovsky, A.F., 2007: Glaciers dominate eustatic sea-level rise in the 21st century. Science 317, 1064-1067. doi: 10.1126/science.1143906

Miller, L., Douglas, B.C., 2007: Gyre-scale atmospheric pressure variations and their relation to 19th and 20th century sea level rise Geophysical Research Letters 34, L16602, doi:10.1029/2007GL030862.

Morton, R.A., Miller, T.L., Moore, L.J., 2004: National assessment of shoreline change: Part 1, Historical shoreline changes and associated coastal land loss along the U.S. Gulf Of Mexico. U.S. Geological Survey Open File Report 2004-1043.

Morton, R.A., Gelfenbaum, G., Jaffe, B.E., 2007: Physical criteria for distinguishing sandy tsunami and storm deposits using modern examples. Sedimentary Geology 200, 184-207. doi:10.1016/j.sedgeo.2007.01.003

Nanayama, F., Shigeno, K., 2006: Inflow and outflow facies from the 1993 tsunami in southwest Hokkaido Sedimentary Geology 187, 139-58. doi:10.1016/j.sedgeo.2005.12.024.

Nanayama, F., Satake, K., Furukawa, R., Shimokawa, K., Atwater, B.F., Shigeno, K., Yamaki, S., 2003: Unusually large earthquakes inferred from tsunami deposits along the Kuril trench Nature 424, 660-63. doi:10.1038/nature01864. 
Nicholls, R.J., Stive, M.J.F., 2004. Society and Sea Level Rise Requires Modelling. Science Magazine, E-Letters. June 2004.

Nicholls, R.J., Wong, P.P., Burkett, V.R., Codignotto, J.O., Hay, J.E., Mclean, R.F., Ragoonaden, S., Woodroffe, C.D., 2007: Coastal systems and low-lying areas. In: Climate Change 2007: Impacts, Adaptation And Vulnerability. Contribution Of Working Group II To The Fourth Assessment Report Of The Intergovernmental Panel On Climate Change [Parry, M.L., Canziani, O.F., Palutikof, J.P., Van Der Linden, P.J., Hanson, C.E., (eds.)] Cambridge University Press, Cambridge, UK.

NOAA, 2007: Billion dollar U.S. weather disasters. http://www.ncdc.noaa.gov/oa/reports/billionz.html [Accessed 11/09/08]

Nott, J. 2003: Waves, coastal boulder deposits and the importance of the pretransport setting. Earth and Planetary Science Letters 210, 269-276. doi:10.1016/S0012-821X(03)00104-3

Otto-Bliesner, B.L., Marshall, S.J., Overpeck, J.T., Miller, G.H., Hu, A., and CAPE Last Interglacial Project members, 2006: Simulating Arctic climate warmth and icefield retreat in the last interglaciation. Science 311, 1751-1753. doi: 10.1126/science. 1120808

Overpeck, J.T., Otto-Bliesner, B.L., Miller, G.H., Muhs, D.R., Alley, R.B., and Kiehl, J.T., 2006: Paleoclimate evidence for future ice-sheet instability and rapid sealevel rise. Science 311, 1747-1750. doi: 10.1126/science.1115159

Paris, R., Wassmer, P., Sartohadi, J., Lavigne, F., Barthomeuf, B., Desgages, E., Grancher, D., Baumert, P., Vautier, F., Brunstein, D., Gomez, C., 2008: Tsunamis as geomorphic crises: lessons from the December 26, 2004 tsunami in Lhok Nga, west Banda Aceh (Sumatra, Indonesia) Geomorphology, In Press, Accepted Manuscript, Available online 3 June 2008. doi:10.1016/j.geomorph.2008.05.040

Parry, M.L., Canziani, O.F., Palutikof, J.P., Van Der Linden, P.J., Hanson, C.E., 2007: Climate Change 2007: Impacts, Adaptation And Vulnerability. Contribution of Working Group II To The Fourth Assessment Report Of The Intergovernmental Panel On Climate Change. Cambridge University Press, Cambridge, UK. 
Pfeffer, W.T., Harper, J.T., O'Neel, S., 2008: Kinematic constraints on glacier contributions to $21^{\text {st }}$-century sea-level rise. Science $321,1340-1343$. doi:10.1126/science.1159099.

Rahmstorf, S., 2007a: A semi-empirical approach to projecting future sea-level rise. Science 315, 368-370. doi: 10.1126/science.1135456

Rahmstorf, S., 2007b: Response to Comments on "A Semi-Empirical Approach to Projecting Future Sea-Level Rise" Science 317, 1866. doi: 10.1126/science.1141283.

Rignot, E., and Kanagaratnam, P., 2006: Changes in the velocity structure of the Greenland ice sheet. Science 311, 986-990. doi: 10.1126/science.1121381

Rodriguez, A.B., Fassell, M.L., Anderson, J.B., 2001: Variations in shoreface progradation and ravinement along the Texas coast, Gulf of Mexico. Sedimentology 48, 837-853. doi: 10.1046/j.1365-3091.2001.00390.x

Sarewitz, D., Pielke Jr., R.A., 2007: The neglected heart of science policy: reconciling supply and demand for science. Environmental Science and Policy 10, 516. doi:10.1016/j.envsci.2006.10.001

Sawai, Y., Fujii, Y., Fujiwara, O., Kamataki, T., Komatsubara, J., Okamura, Y., Satake, K., Shishikura, M., 2008: Marine incursions of the past 1500 years and evidence of tsunamis at Suijin-Numa, a coastal lake facing the Japan trench The Holocene 18, 517-528. doi: 10.1177/0959683608089206

Scheffers, A., 2002: Paleotsunami Evidences from Boulder Deposits on Aruba, Curaçao and Bonaire. Science of Tsunami Hazards 20, 26-37.

Scheffers, A., Scheffers, S., 2007: Tsunami deposits on the coastline of west Crete (Greece) Earth and Planetary Science Letters 259, 613-624. doi:10.1016/j.epsl.2007.05.041

Scheffers, S.R., Scheffers, A., Kelletat, D., Bryant, E.A., 2008a: The Holocene paleo-tsunami history of West Australia Earth and Planetary Science Letters 270, 137-146. doi:10.1016/j.epsl.2008.03.027

Scheffers, A., Kelletat, D., Vött, A., May, S.M., Scheffers, S., 2008b: Late Holocene tsunami traces on the western and southern coastlines of the Peloponnesus (Greece) Earth and Planetary Science Letters 269, 271-279. doi:10.1016/j.epsl.2008.02.021 
Scicchitano, G., Monaco, C., Tortorici, L., 2007: Large boulder deposits by tsunami waves along the Ionian coast of south-eastern Sicily (Italy) Marine Geology 238, 75-91. doi:10.1016/j.margeo.2006.12.005

Scileppi, E., Donnelly, J.P., 2007: Sedimentary evidence of hurricane strikes in western Long Island, New York Geochemistry, Geophysics, Geosystems 8, Q06011. doi:10.1029/2006GC001463

Shennan, I., Horton, B.P., 2002: Relative sea-level changes and crustal movements of the UK. Journal of Quaternary Science 16, 511-526. doi: 10.1002/jqs.710

Schmith, T., Johansen, S., Thejll, P., 2007: Comment on "A Semi-Empirical Approach to Projecting Future Sea-Level Rise" Science 317, 1866 doi: 10.1126/science. 1143286

Small, C., Nicholls, R.J., 2003: A global analysis of human settlement in coastal zones Journal of Coastal Research 19, 584-599.

Smith, J.N., 2001: Why should we believe ${ }^{210} \mathrm{~Pb}$ sediment geochronologies? Journal of Environmental Radioactivity 55, 121-123. doi:10.1016/S0265-931X(00)00152-1.

Sparrenbom, C., Bennike, O., Björck, S., Lambeck, K., 2006: Relative sea-level changes since 15,000 cal. yrs BP in the Nanortalik area, southern Greenland Journal of Quaternary Science 21, 29-48.

Spiske, M., Böröcz, Z., Bahlburg, H., 2008: The role of porosity in discriminating between tsunami and hurricane emplacement of boulders - a case study from the Lesser Antilles, southern Caribbean Earth and Planetary Science Letters 268, 384396. doi:10.1016/j.epsl.2008.01.030

Stanley, D.J., Hait, A.K., 2000: Deltas, Radiocarbon Dating, and Measurements of Sediment Storage and Subsidence. Geology 28, 295-298 doi: 10.1130/00917613(2000)28<295:DRDAMO>2.0.CO;2

Stive, M.J.F., 2004: How important is global warming for coastal erosion? Climatic Change 64, 27-39.

Stolper, D., List, J.H., Thieler, E.R., 2005: Simulating the evolution of coastal morphology and stratigraphy with a new morphological-behaviour model (GEOMBEST). Marine Geology 218, 17-36. doi:10.1016/j.margeo.2005.02.019

Storms, J.E.A., Weltje, G.J., van Dijke, J.J., Geel, C.R., Kroonenberg, S.B., 2002: Process-response modeling of wave-dominated coastal systems: simulating 
evolution and stratigraphy on geological timescales. Journal of Sedimentary Research 72, 226-239. doi: 10.1306/052501720226

Tappin, D.R., 2007: Sedimentary features of tsunami deposits - Their origin, recognition and discrimination: An introduction. Sedimentary Geology 200, 1-4. doi:10.1016/j.sedgeo.2007.01.001.

Tarasov, L., Peltier, W.R., 2002: Greenland glacial history and local geodynamic consequences Geophysical Journal International 150, 190-229.

Törnqvist, T.E., Bick, S.J., González, J.L., van Der Borg, K., de Jong, A.F.M., 2004a: Tracking the Sea-Level Signature of the $8.2 \mathrm{Ka}$ Cooling Event: New Constraints from the Mississippi Delta. Geophysical Research Letters 31, L23309. doi:10.1029/2004gl021429

Törnqvist, T.E., González, J.L., Newsom, L.A., van der Borg, K., de Jong, A.F., Kurnik, C.W., 2004b: Deciphering Holocene Sea-Level History on the U.S. Gulf Coast: A High-Resolution Record from the Mississippi Delta. Geological Society Of America Bulletin 116, 1026-1039. doi: 10.1130/B2525478.1

Törnqvist, T.E., Bick, S.J., van der Borg, K., de Jong, A.F.M., 2006: How Stable is the Mississippi Delta? Geology 34, 697-700. doi: 10.1130/G22624.12006

Törnqvist, T.E., Paola, C., Parker, G., Liu, K., Mohrig, D., Holbrook, J.M., Twilley, R.R., 2007: Comment on "Wetland Sedimentation From Hurricanes Katrina And Rita" Science 316, 201. doi: 10.1126/science.1136780

Trenberth, K.E., Caron, J.M., Stepaniak, D.P., Worley, S., 2002: Evolution of EI Niño - Southern Oscillation and global atmospheric surface temperatures Journal of Geophysical Research 107(D8), 4065, doi:10.1029/2000JD000298.

Tribbia, J., Moser, S.C., 2008: More than information: what coastal managers need to plan for climate change. Environmental Science and Policy 11, 315-328. doi:10.1016/j.envsci.2008.01.003

Tsimplis, M.N., Baker, T.F., 2000: Sea level drop in the Mediterranean Sea: an indicator of deep water salinity and temperature changes? Geophysical Research Letters 27 (12), 1731-1734.

Tsimplis, M.N., Josey, S.A., 2001: Forcing of the Mediterranean Sea by atmospheric oscillations over the North Atlantic Geophysical Research Letters 28(5), 803-806, 10.1029/2000GL012098. 
Tsimplis M.N., Álvarez-Fanjul, E., Gomis, D., Fenoglio-Marc, L., Pérez, B., 2005: Mediterranean sea level trends: atmospheric pressure and wind contribution. Geophysical Research Letters 32, L20602, doi:10.1029/2005GL023867.

Turetsky, M.R., Manning, S.W., Wieder, R.K., 2004: Dating Recent Peat Deposits. Wetlands 24 (2), 324-356. DOI: 10.1672/0277-5212(2004)024[0324:DRPD]2.0.CO;2 Turner, R.E., Baustian, J.J., Swenson, E.M., Spicer, J.S., 2006: Wetland Sedimentation from Hurricanes Katrina and Rita. Science 314, 449-452. doi: 10.1126/science. 1129116

Turner, R.E., Baustian, J.J., Swenson, E.M., Spicer, J.S., 2007: Response to Comment on "Wetland Sedimentation from Hurricanes Katrina and Rita. Science 316, 201. doi: 10.1126/science.1136869

Turney, C.S.M., Brown, H., 2007: Catastrophic early Holocene sea level rise, human migration and the Neolithic transition in Europe. Quaternary Science Reviews 26, 2036-2041. doi:10.1016/j.quascirev.2007.07.003

van de Wal, R.S.W., Boot, W., van den Broeke, M.R., Smeets, C.J.P.P., Reijmer, C.H., Donker, J.J.A., Oerlemans J., 2008: Large and rapid melt-induced velocity changes in the ablation zone of the Greenland Ice Sheet. Science 321, 111-113. doi: 10.1126/science. 1158540

van der Veen, C.J., 2007: Fracture propagation as means of rapidly transferring surface meltwater to the base of glaciers. Geophysical Research Letters, 34, L01501. doi:10.1029/2006GL028385

Velicogna, I., Wahr, J., 2006: Measurements of time-variable gravity show mass loss in Antarctica. Science 311, 1754-1756. doi: 10.1126/science.1123785

Vink, A., Steffen, H., Reinhardt, L., Kaufmann, G., 2007: Holocene relative sealevel change, isostatic subsidence and the radial viscosity structure of the mantle of northwest Europe (Belgium, the Netherlands, Germany, southern North Sea). Quaternary Science Reviews 26, 3249-3275.

Vogel, S.W., 2008: Cryosphere: Fire and Ice. Nature Geoscience 1, 91-92. doi: 10.1038/ngeo117

Vogel, S.W., Tulaczyk, S. 2006: Ice-dynamical constraints on the existence and impact of subglacial volcanism on West Antarctic ice sheet stability Geophysical Research Letters 33, L23502. doi:10.1029/2006GL027345 
Walkden, M., Dickson, M., 2008: equilibrium erosion of soft rock shores with a shallow or absent beach under increased sea level rise. Marine Geology 251, 75-84. doi:10.1016/j.margeo.2008.02.003

Webster, P.J., 2008: Myanmar's deadly daffodil. Nature Geoscience 1, 488-490. doi: $10.1038 /$ ngeo257

Webster, P.J., Holland, G.J., Curry, J.A., Chang, H.-R., 2005: Changes in tropical cyclone number, duration, and intensity in a warming environment Science 309, 1844-1846. doi: 10.1126/science.1116448.

White, N.J., Church, J.A., Gregory, J.M., 2005: Coastal and global averaged sea level rise for 1950 to 2000 Geophysical Research Letters 32, L01601, doi:10.1029/2004GL021391.

Wijffels, S.E., Willis, J.K., Domingues, C.M., Barker, P., White, N.J., Gronell, A., Ridgway, K., Church, J.A. 2008: Changing eXpendable bathythermograph fall-rates and their impact on estimates of thermosteric sea level rise Journal of Climate (in press)

Wilch, T.I., McIntosh, W.C., Dunbar, N.W., 1999: Late Quaternary volcanic activity in Marie Byrd Land: Potential Ar-40/Ar-39-dated time horizons in West Antarctic ice and marine cores Geological Society of America Bulletin 111, 1563-1580. doi: 10.1130/0016-7606(1999)111<1563:LQVAIM>2.3.CO;2

Winberry, J.P., Anandakrishnan, S., 2004: Crustal structure of the West Antarctic rift system and Marie Byrd Land hotspot Geology 32, 977-980. DOI: 10.1130/G20768.1.

Woodroffe, C.D., 2003: Coasts: Form, Process and Evolution. Cambridge University Press, $623 \mathrm{pp}$.

Woodworth, P.L., 1987: Trends in UK mean sea level Marine Geodesy 11, 57-87.

Woodworth, P.L., 1990: A search for accelerations in records of European mean sea level International Journal of Climatology 10, 129-143.

Woodworth, P.L., 2006: Some important issues to do with long term sea level change Philosophical Transactions of the Royal Society A 364, 787-803. doi:10.1098/rsta.2006.1737. 
Woodworth, P.L., Flather, R.A., Williams, J.A., Wakelin, S.L., Jevrejeva S., 2007: The dependence of UK extreme sea levels and storm surges on the North Atlantic Oscillation. Continental Shelf Research 27, 935-946. doi:10.1016/j.csr.2006.12.007

Woodworth, P.L., White, N.J., Jevrejeva, S., Holgate, S.J., Church, J.A., Gehrels, W.R., 2008: Evidence for the accelerations of sea level on multi-decade and century timescales International Journal of Climatology, in press. 